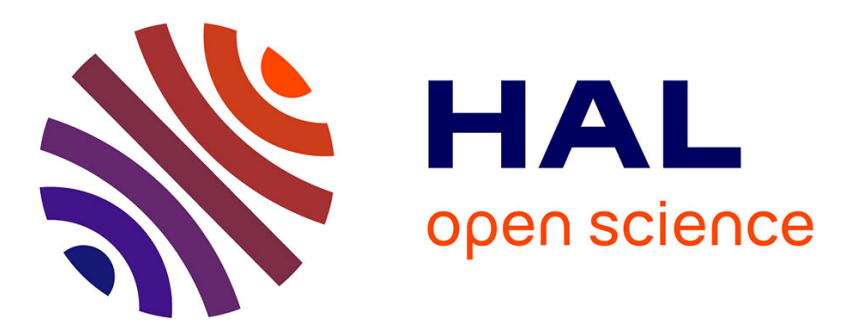

\title{
Antiplasmodial activities of gold(I) complexes involving functionalized N-heterocyclic carbenes
}

\author{
Catherine Hemmert, Arba Pramundita Ramadani, Luca Boselli, Alvaro \\ Fernandez Alvarez, Lucie Paloque, Jean-Michel Augereau, Heinz Gornitzka, \\ Françoise Benoit-Vical
}

\section{To cite this version:}

Catherine Hemmert, Arba Pramundita Ramadani, Luca Boselli, Alvaro Fernandez Alvarez, Lucie Paloque, et al.. Antiplasmodial activities of gold(I) complexes involving functionalized N-heterocyclic carbenes. Bioorganic and Medicinal Chemistry, 2016, 24 (13), pp.3075-3082. 10.1016/j.bmc.2016.05.023 . hal-01937596

\section{HAL Id: hal-01937596 https://hal.science/hal-01937596}

Submitted on 21 May 2021

HAL is a multi-disciplinary open access archive for the deposit and dissemination of scientific research documents, whether they are published or not. The documents may come from teaching and research institutions in France or abroad, or from public or private research centers.
L'archive ouverte pluridisciplinaire HAL, est destinée au dépôt et à la diffusion de documents scientifiques de niveau recherche, publiés ou non, émanant des établissements d'enseignement et de recherche français ou étrangers, des laboratoires publics ou privés. 


\section{Antiplasmodial activities of gold(I) complexes involving functionalized $N$ - heterocyclic carbenes}

Catherine Hemmert ${ }^{\mathrm{a}, \mathrm{b}, *}$, Arba Pramundita Ramadani ${ }^{\mathrm{a}, \mathrm{b}, \mathrm{c}}$, Luca Boselli ${ }^{\mathrm{a}, \mathrm{b}}$, Álvaro Fernández Álvarez $^{\mathrm{a}, \mathrm{b}}$, Lucie Paloque ${ }^{\mathrm{a}, \mathrm{b}}$, Jean-Michel Augereau ${ }^{\mathrm{a}, \mathrm{b}}$, Heinz Gornitzka ${ }^{\mathrm{a}, \mathrm{b}, *}$, Françoise Benoit-Vical ${ }^{\mathrm{a}, \mathrm{b}, *}$

${ }^{a}$ CNRS, LCC (Laboratoire de Chimie de Coordination), 205 route de Narbonne, BP 44099, F-31077 Toulouse Cedex 4, France

${ }^{b}$ Université de Toulouse, UPS, INPT, F-31077 Toulouse Cedex 4, France

${ }^{c}$ Present address : Faculty of Medicine, Universitas Gadjah Mada, Yogyakarta, Indonesia

Keywords: $N$-heterocyclic carbene, Gold, Organometallic complexes, Antiplasmodial drugs.

* Corresponding authors.

E-mail addresses: Catherine.Hemmert@lcc-toulouse.fr; Heinz.Gornitzka@lcc-toulouse.fr;

Francoise.Vical@inserm.fr 


\begin{abstract}
A series of twenty five molecules, including imidazolium salts functionalized by $\mathrm{N}-$, O- or S-containing groups and their corresponding cationic, neutral or anionic gold(I) complexes were evaluated on Plasmodium falciparum in vitro and then on Vero cells to determine their selectivity. Among them, eight new compounds were synthesized and fully characterized by spectroscopic methods. The X-ray structures of three gold(I) complexes are presented. Except one complex (18), all the cationic gold(I) complexes show potent antiplasmodial activity with $\mathrm{IC}_{50}$ in the micro- and submicromolar range, correlated with their lipophilicity. Structureactivity relationships enable to evidence a lead-complex (21) displaying a good activity $\left(\mathrm{IC}_{50}=\right.$ $210 \mathrm{nM})$ close to the value obtained with chloroquine $\left(\mathrm{IC}_{50}=514 \mathrm{nM}\right)$ and a weak cytotoxicity.
\end{abstract}




\section{Introduction}

According to the latest estimates, malaria led to about 500000 deaths in 2015 with $70 \%$ of all deaths for children aged under 5 years. ${ }^{1}$ Thanks to global fight against vectors and the large use of artemisinin-based combination therapies (ACT), estimated malaria mortality rates decreased by $60 \%$ worldwide between 2000 and 2015. ${ }^{1}$ Unfortunately, ACT resistance is now reported in many South-east Asia countries whereas there are no other antiplasmodial drugs to replace them. ${ }^{1}$ New drugs with alternative chemical structures are urgently needed.

The peculiar biological properties of some organometallic compounds have helped in the development of new drugs based on metal complexes for major medical human problems including mainly cancer along with bacterial, viral and parasitic infections. ${ }^{2}$ Generally, metal complexes are subject to modifications (ligand substitution and/or redox reactions) during uptake and transport inside the human body; this will influence the reactivity of the metal, but also greatly affect the absorption and delivery of the complex, and sometimes even the specificity of target recognition so they are therefore almost always "pro-dugs". Metals may also be used to enhance the efficacy of known organic drugs and the metal-drug synergism results in the enhancement of the activity of the parental organic drug due to binding to the metal ion. More specifically, numerous metal-containing compounds have been evaluated as antimalarial agents and a recent review overviewed the advancements in this field during the last three decades. ${ }^{3}$ Among metal coordination complexes in which the metal center is directly coordinated to a known organic drug, gold and ruthenium complexes containing chloroquine (CQ) or analogs were the most active (with $\mathrm{IC}_{50}$ in the $\mathrm{nM}$ range), with improved efficacy, when compared to the drug, against CQ-sensitive and CQ-resistant strains, in vitro and in vivo. ${ }^{4}$ In particular, the principal mechanism proposed for the antimalarial action of $\left[\mathrm{Au}(\mathrm{CQ})\left(\mathrm{PPh}_{3}\right)\right] \mathrm{PF}_{6}$ against resistant strains of $P$. falciparum is the interaction with heme and the inhibition of $\beta$-hematin formation. Both the enhanced activity and the ability of this 
compound to lower CQ-resistance are related to the high lipophilicity of the metal complex and the important structural modification of the CQ structure imposed by the presence of the metalcontaining fragment. ${ }^{4 a}$ A great success was obtained by C. Biot and coll. with impressive biological results in the introduction of a ferrocenyl moiety into the lateral side chain of CQ, leading to the bioorganometallic drug Ferroquine (FQ) which is more active than CQ, and equally active against CQ-susceptible and CQ-resistant clones. ${ }^{5}$ The potent activity of FQ and the absence of cross-resistance with other antimalarials were reported both in vitro on a large number of clones and field isolates of $P$. falciparum, and in vivo on rodent models that demonstrated the high bioavailability of the product. ${ }^{5 \mathrm{~d}} \mathrm{FQ}$ has been developed by Sanofi and is the only metallodrug that has entered clinical trials (Phase IIb) against malaria, currently evaluated in combination with Artefenomel (OZ439). ${ }^{5 f}$ FQ has a multi-mode of action: a capacity to target lipids, an ability to inhibit the formation of hemozoin, and to generate reactive oxygen species. ${ }^{5 e, 6}$

NHCs represent one of the most important classes of ligands in organometallic chemistry. The easy preparation of NHC-precursors has allowed an almost infinite access to new organometallic complexes, in which the nitrogen atoms of the azoliums rings can be functionalized by organic groups, organometallic moieties and biologic entities. NHCs are extremely good $\sigma$-donors, making strong metal-carbene bonds and giving stable complexes in biological medium. Numerous NHC-metal complexes exhibit very interesting biological activities as reflected in several review articles. ${ }^{7}$ By varying the properties of the NHCs and the nature of the metals (mainly $\mathrm{Cu}, \mathrm{Ag}, \mathrm{Au}, \mathrm{Ni}, \mathrm{Pd}, \mathrm{Pt}$ and $\mathrm{Ru}$ ), different important diseases have been targeted, mainly fungi ${ }^{7 b, 7 i}$, bacteria ${ }^{7 b-d, 7 i}$, and cancer. ${ }^{7 \mathrm{a}-\mathrm{f}, 7 \mathrm{~h}-\mathrm{k}}$. We focused our research on heteroditopic $\mathrm{N}$-heterocyclic carbene (NHC) gold(I) complexes for their biomedical potential in anticancer and parasitic diseases such as malaria and leishmaniasis. ${ }^{8}$ New gold(I) complexes containing two 1-[2-(diethylamino)ethyl]imidazolydene ligands have been synthetized and 
their anticancer activity reported in five representative human cancer cell cancers (prostate, breast, brain, lung and liver) lines. ${ }^{8 a}$ Very recently, we have demonstrated that mononuclear cationic and especially neutral gold(I) NHC-quinoline proved to be promising metallodrugs with potent and selective action against the pathological relevant form (intramacrophagic amastigote) of Leishmania. ${ }^{8 \mathrm{~d}}$ Moreover, we have previously synthetized and tested against Plasmodium falciparum dinuclear dimeric and mononuclear gold(I) complexes and we have shown that mononuclear cationic gold(I) complexes containing aromatic amino-functionalized NHC exhibit in vitro potent and non-toxic antiplasmodial activity against the chloroquineresistant strain FcM29-Cameroon with $\mathrm{IC}_{50}$ values up to $330 \mathrm{nM} .^{8 \mathrm{c}}$

The rational design of new gold $\mathrm{N}$-functionalized NHCs complexes with specific and/or selective parasite targets appear thus as a very useful avenue in the antiplasmodial drug research.

In this work, we aim to extend our preliminary work concerning gold(I) NHCs complexes against Plasmodium falciparum by fine tuning and studying the key building blocks of these organometallic molecules. For this purpose, we report the antiplasmodial activity of our gold(I) complexes already described for other biomedical applications. ${ }^{8 c}$ In addition, we report the preparation, characterization and antimalarial potential of new mononuclear cationic, anionic and neutral gold(I) NHC or bis(NHC) complexes.

\section{Results and discussion}

\subsection{Chemistry and structural characterization}

The synthesis of proligands 1-8 was already described (Scheme 1). ${ }^{8 \mathrm{a}, 8 \mathrm{c}, 8 \mathrm{~d}}$ The imidazolium salts 9 and 11 were simply obtained after a quaternization step of 1-arylimidazole, namely 1(4-methylthiophenyl)-1H-imidazole and 1-(4-hydroxyphenyl)imidazole, respectively, with one 


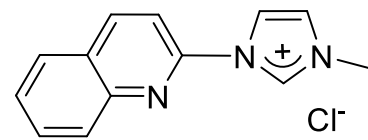

$1^{a}$
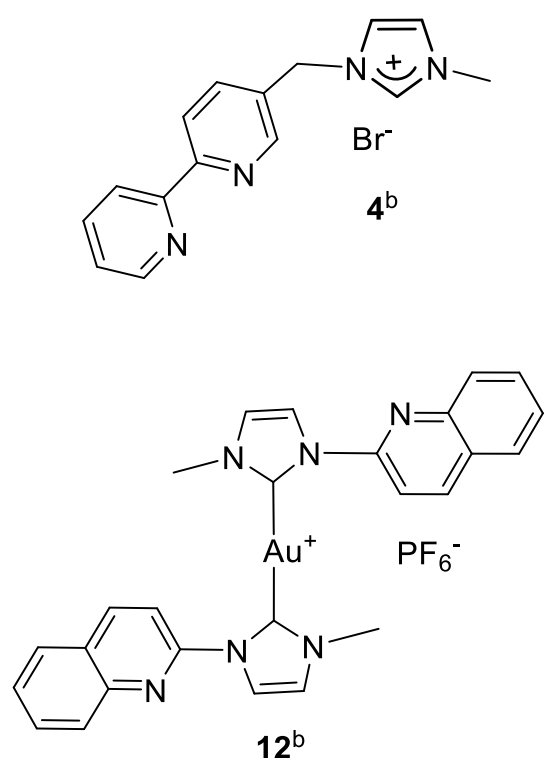

$12^{b}$

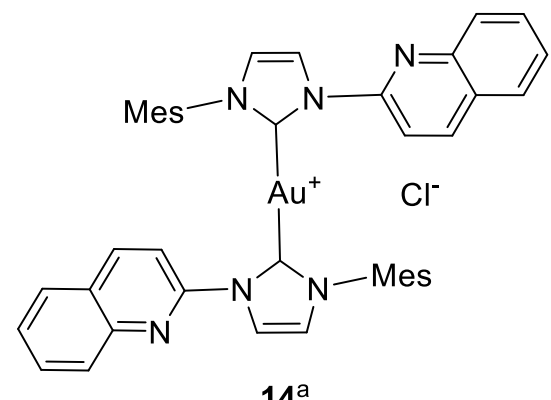

$14^{a}$

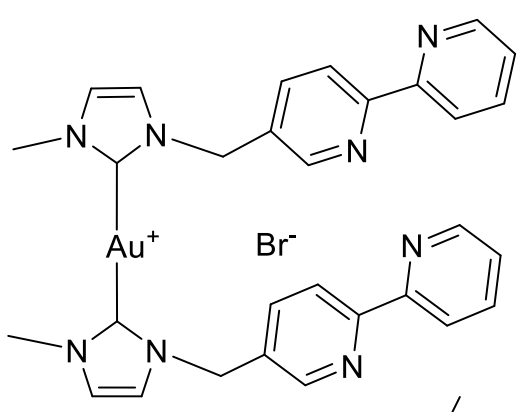

$16^{b}$<smiles>Cn1cc[n+](-c2ccc3ccccc3n2)c1</smiles>

$2^{a}$<smiles>C[SH](=O)(c1ccccc1)n1cc[n+](-c2ccc3ccccc3n2)c1</smiles>

$3^{a}$<smiles></smiles>

$5^{\mathrm{c}}, \mathrm{R}=\mathrm{Me}$

6 $^{\mathrm{C}}, \mathrm{R}=n \mathrm{Bu}$

$7^{c}, \mathrm{R}=\mathrm{Bn}$

$8^{c}, R=$ Mes<smiles>CN1C=CN(c2ccc3ccccc3n2)C1[14C](Cl)[Cl+]</smiles>

$13^{a}$<smiles></smiles>

$15^{a}$<smiles></smiles>

Scheme 1. Proligands and gold(I) complexes used in this study. ${ }^{a}$ Ref. $8 d,{ }^{b}$ Ref. $8 \mathrm{c},{ }^{\mathrm{c}}$ this work and ${ }^{\mathrm{d}}$ Ref. 8a. 
equivalent of benzylchloride and $\mathrm{KPF}_{6}$ at $80^{\circ} \mathrm{C}$ in acetonitrile (Scheme 2). The zwitterionic proligand 10 was easily synthetized by heating stoichiometric amounts of benzylimidazole and bromoacetic acid at $130{ }^{\circ} \mathrm{C}$, following by deprotonation of the acidic proton by addition of $\mathrm{Na}_{2} \mathrm{CO}_{3}$ under reflux in water. The most notable features in the ${ }^{1} \mathrm{H}$ and ${ }^{13} \mathrm{C}$ NMR spectra of the imidazolium salts are the resonances for imidazolium protons $\left(H_{2}\right)$ located at 9.97, 9.21 and $10.16 \mathrm{ppm}$ and the corresponding imidazolium carbons $\left(C_{2}\right)$ in the range of 135.6-164.0 ppm, for 9, 10 and 11 respectively. The high resolution mass spectra (ES) of proligands 9 and 11 exhibit the classical peak corresponding to the cation $\left[\mathrm{M}-\mathrm{PF}_{6}\right]^{+}$and that of zwitterion $\mathbf{1 0}$ shows the cation $\left[\mathrm{M}+\mathrm{H}^{+}\right]$.

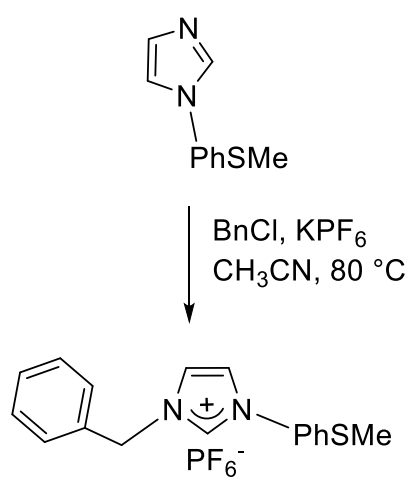

9, $90 \%$

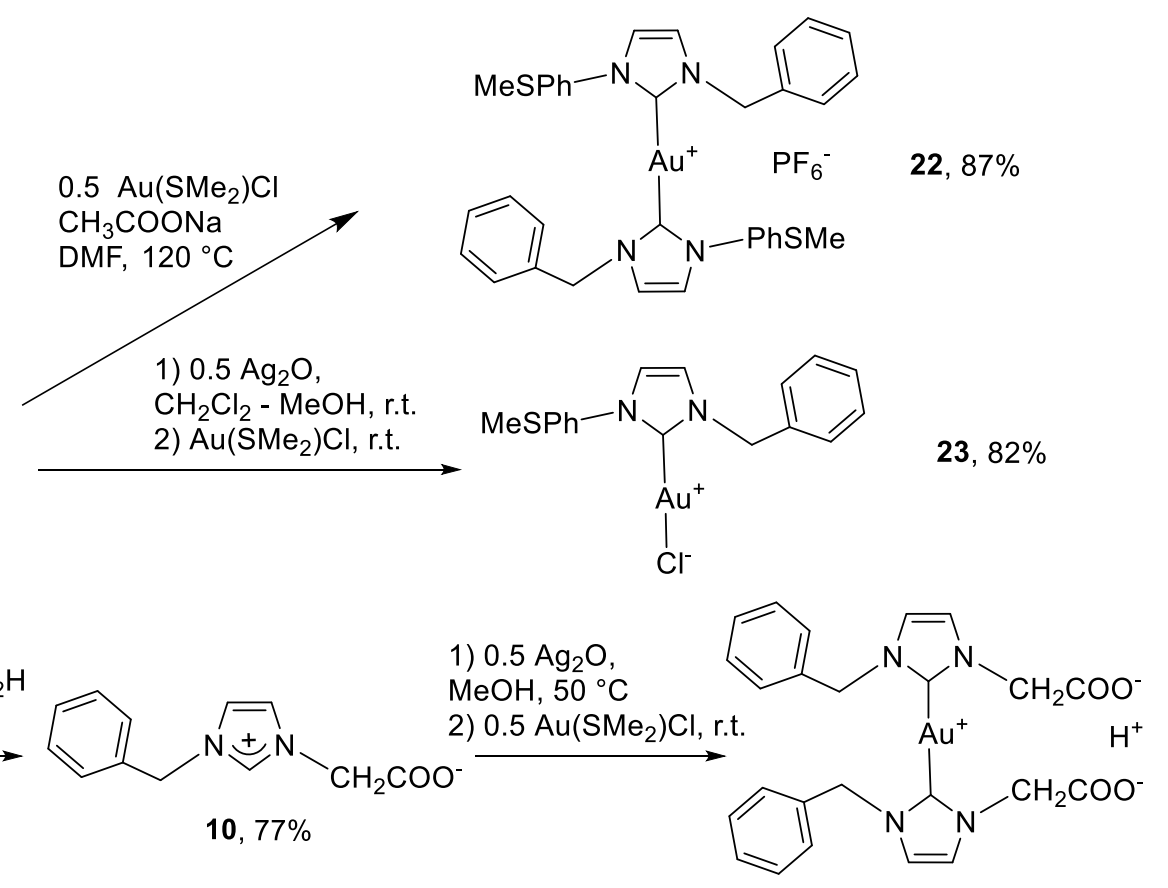

$24,83 \%$
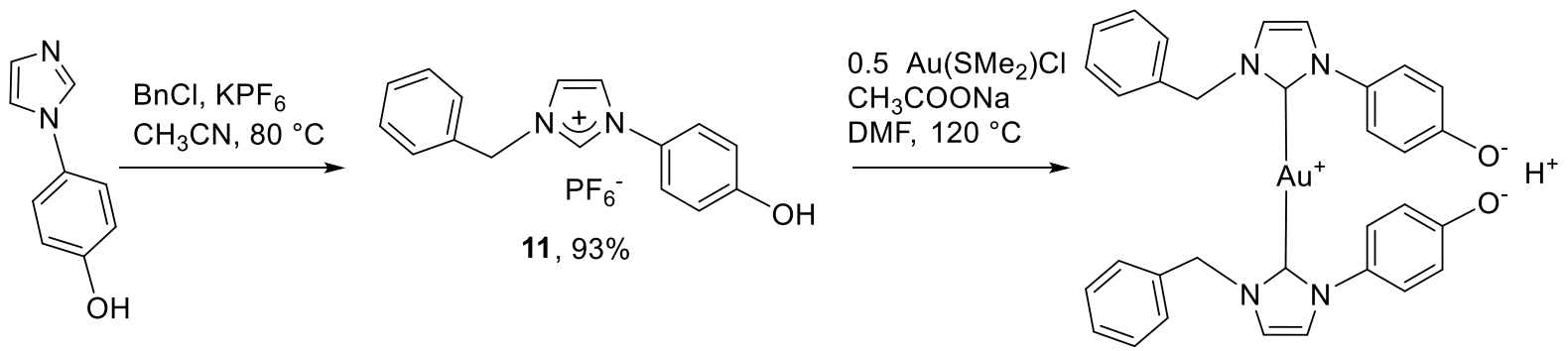

$25,66 \%$

Scheme 2. Synthesis of imidazoliums salts 9-11 and gold(I) bis(NHC) complexes 23-25. 
The synthesis of complexes 12-16 and 18-21 was previously reported in the literature (Scheme 1). ${ }^{8 \mathrm{a}, 8 \mathrm{c}, 8 \mathrm{~d}}$ The mononuclear gold(I) bis(NHC) complexes 22 and $\mathbf{2 5}$ (Scheme 2) were prepared according a classical way, from the $N$-functionalized imidazolium salts $\mathbf{9}$ or $\mathbf{1 1}$, respectively and one half equivalent of $\mathrm{Au}\left(\mathrm{SMe}_{2}\right) \mathrm{Cl}$ with sodium acetate as a mild base in hot $\mathrm{N}, \mathrm{N}$-dimethylformamide $\left(120^{\circ} \mathrm{C}\right)$ and were isolated as white or beige powders with good yields (66-87\%). It has to be mentioned that in the ${ }^{1} \mathrm{H}$ NMR of complex 24 , both protons of the $\mathrm{CH}_{2} \mathrm{COO}^{-}$become inequivalent. This could be due to the interaction of the two carboxylate with a proton, which may impede the free rotation of the $\mathrm{CH}_{2}$. Moreover, for complex 25 the phenol functions are depronated during the complexation process which is supported by the absence of the $\mathrm{OH}$ proton in the ${ }^{1} \mathrm{H}$ NMR spectrum (the $\mathrm{OH}$ proton of proligand $\mathbf{1 1}$ was located at $10.16 \mathrm{ppm}$ ) and by the ES-HRMS spectrum showing the molecular peak $\left[\mathrm{M}+\mathrm{H}^{+}\right]$at $m / z$ 697.1874 with $\mathrm{M}=$ Au ${ }^{\mathrm{I}}$ bis(NHC-phenolato). The neutral gold(I) NHC complexes $\mathbf{1 7}$ and 23 and the anionic complex gold(I) bis(NHC) 24 (Schemes 1 and 2) were synthetized via the convenient transmetalation route. Firstly, the silver precursor complexes were prepared by deprotonation of the imidazolium salts $\mathbf{4}, \mathbf{9}$ or $\mathbf{1 0}$, with one half equivalent of the mild base $\mathrm{Ag}_{2} \mathrm{O}$ in a mixture of $\mathrm{CH}_{2} \mathrm{Cl}_{2}-\mathrm{MeOH}$ at room temperature or in $\mathrm{MeOH}$ at $50{ }^{\circ} \mathrm{C}$. For 17 , the silver species $\operatorname{Ag}(\mathbf{4})_{2} \mathrm{Br}^{8 \mathrm{c}}$ was isolated before the carbene transfer reaction while for compounds $\mathbf{2 3}$ and 24, the transmetalation was carried out in situ, by adding one (for $\mathbf{1 7}$ and $\mathbf{2 3}$ ) or one half equivalent (for 24) of $\mathrm{Au}\left(\mathrm{SMe}_{2}\right) \mathrm{Cl}$, with respect to the ligand. The three later compounds were obtained as grey solids with high yields (82-85\%) and all complexes are stable towards air and moisture. NMR spectroscopy unequivocally demonstrates the formation of the gold(I) complexes; the ${ }^{13} \mathrm{C}$ spectra show the resonance for the carbene carbon atoms between 181.6 and $184.5 \mathrm{ppm}$ for the gold(I) bis(NHC) complexes 22, 24 and 25, and at 172.0 and $168.9 \mathrm{ppm}$ for the neutral species $\mathbf{1 7}$ and $\mathbf{2 3}$, respectively. These values are in the range of reported values for $\mathrm{Au}^{\mathrm{I}}-\mathrm{NHC}$ complexes having $\mathrm{C}-\mathrm{Au}-\mathrm{X}(\mathrm{X}=$ halide $)$ or $\mathrm{C}-\mathrm{Au}-\mathrm{C}$ motifs. ${ }^{9}$ The elemental 
analysis of the gold(I) complexes are in agreement with the proposed structures and the high resolution mass spectra (ES) exhibit the classical peaks corresponding to the cationic fragments $[\mathrm{M}+\mathrm{H}]^{+}$for the neutral and the anionic complexes 17, 23-25 and $\left[\mathrm{M}-\mathrm{PF}_{6}^{-}\right]^{+}$for the cationic compound 22.

Crystals of 17 suitable for X-ray diffraction analysis were obtained by slow evaporation of a chloroform solution of $\mathbf{1 7}$.

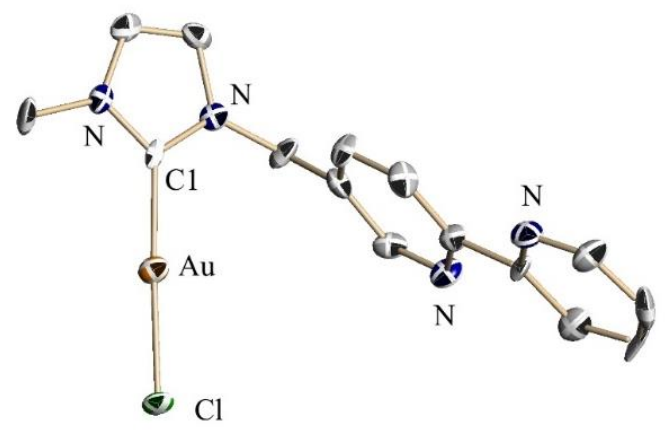

Figure 1. Structure of $\mathbf{1 7}$ in the solid state, thermal ellipsoids are depicted at a 50\% level. Hydrogen atoms have been omitted for clarity. Selected bond lengths $[\AA]$ and angles $\left[{ }^{\circ}\right]$ : $\mathrm{C} 1$ $\mathrm{Au}=1.99(2), \mathrm{Au}-\mathrm{Cl}=2.30(1), \mathrm{C} 1-\mathrm{Au}-\mathrm{Cl}=177.7(4)$.

Slow evaporation of a $\mathrm{MeOH}$ solution of $\mathbf{2 2}$ gave crystals suitable for X-ray diffraction analysis.

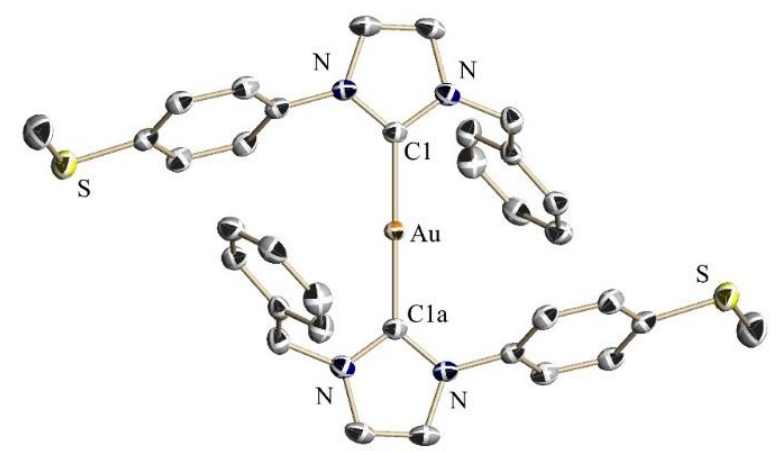

Figure 2. Structure of the cationic part of $\mathbf{2 2}$ in the solid state, thermal ellipsoids are depicted at a 50\% level. Hydrogen atoms and the uncoordinated $\mathrm{PF}_{6}$ anion have been omitted for clarity. Selected bond lengths $[\AA]$ and angles $\left[{ }^{\circ}\right]: \mathrm{C} 1-\mathrm{Au}=2.013(2), \mathrm{Au}-\mathrm{C} 1 \mathrm{a}=2.013(2), \mathrm{C} 1-\mathrm{Au}-\mathrm{C} 1 \mathrm{a}=$ 180. 
Crystals of $\mathbf{2 3}$ suitable for X-ray diffraction analysis were obtained by slow evaporation of an acetonitrile solution of $\mathbf{2 3}$.

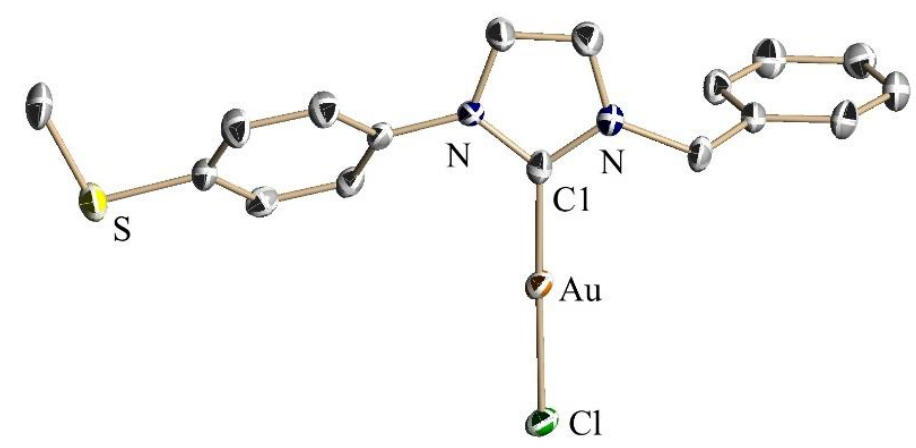

Figure 3. Structure of $\mathbf{2 3}$ in the solid state, thermal ellipsoids are depicted at a $50 \%$ level. Hydrogen atoms have been omitted for clarity. Selected bond lengths $[\AA]$ and angles $\left[{ }^{\circ}\right]$ : $\mathrm{C} 1-$ $\mathrm{Au}=1.972(5), \mathrm{Au}-\mathrm{Cl}=2.287(2), \mathrm{C} 1-\mathrm{Au}-\mathrm{Cl}=178.2(2)$.

All carbon-gold and chlorine-gold distances, as well as the carbon-gold-carbon and carbongold-chlorine angles are in the normal range for such compounds. In 22 the gold cation is located on an inversion center and both NHC ring systems are absolutely coplanar. Moreover, the benzyl substituents are in trans position.

\subsection{Anti-malarial activity and selectivity}

Twenty five molecules, involving imidazoliums salts 1-11 and mononuclear gold(I) complexes 12-25 were screened in vitro against $P$. falciparum strains (Table 1) by determining their $50 \%$ inhibitory concentrations ( $\mathrm{IC}_{50}$ ) and compared to the antimalarial reference-drugs chloroquine and artemisinin. As expected, proligands 1 and 4-11 showed weak or no activity with $\mathrm{IC}_{50}$ values ranging from 6.4 to $>230 \mu \mathrm{M}$, the worst value being obtained for the neutral zwitterionic species 10, all other imidazoliums salts being cationic. More surprising, the two proligands $\mathbf{2}$ and $\mathbf{3}$ containing both a quinoline entity and an aryl directly branched on the azolium ring exhibit interesting antiplasmodial potency with $\mathrm{IC}_{50}$ values of 1.4 and $1.5 \mu \mathrm{M}$, 
respectively. As expected, an enhanced activity was observed for the tested gold(I) complexes 12, 15-16 and 19-22 when compared to the corresponding starting proligands, except for the couple $\mathbf{2 / 1 4}$ showing similar activity. This set of results corroborates in most cases the key role of the gold cation in antiprotozoal activity against $P$. falciparum. The three neutral complexes 13, 17 and 23 showed moderate activity with $\mathrm{IC}_{50}$ comprised between 4.1 and $6.6 \mu \mathrm{M}$ and the IC $_{50}$ values of the two anionic compounds $\mathbf{2 4}$ and $\mathbf{2 5}$ are in the same order of magnitude, 5.6 $\mu \mathrm{M}$ and $3.7 \mu \mathrm{M}$, respectively. With the exception of complex 18, the best values on $P$. falciparum were obtained for the cationic $\mathrm{Au}(\mathrm{I})$ bis(NHC) species with $\mathrm{IC}_{50}$ in the micromolar and submicromolar range, with $2.1 \mu \mathrm{M}(\mathbf{1 9}), 0.48 \mu \mathrm{M}(\mathbf{2 0}), 0.21 \mu \mathrm{M}(\mathbf{2 1})$, and $0.32 \mu \mathrm{M}(\mathbf{2 2})$. A first insight can emerge from these results and confirm our preliminary published results (concerning 12 and $\mathbf{1 6}^{8 \mathrm{c}}$ ): the global charge of the complex constitutes an important factor and cationic compounds are correlated with an increase antiplasmodial activity. The same antiplasmodial properties were reported with albitiazolium, a bis cationic compound witch reached the clinical $2 \mathrm{~b}$ step for antimalarial drug development. Albitiazolium had shown its entry facilitated by a poly-specific cation transporter present in the parasite membrane. ${ }^{10}$ The cationic property could facilitate the accumulation of the molecules inside the parasite where the $\mathrm{pH}$ of the cytoplasm is approximately 7.15 but certainly not in the malaria digestive vacuole where $\mathrm{pH}$ is about $5 .{ }^{11}$ Moreover, even if the carbenic ligand acts mainly as a carrier for the metal center towards its target(s), as it is generally the case for gold complexes with biological potential, the two substituents on the NHC plays a crucial role with regard to the antiparasitic efficiency. This is well illustrated for the gold(I) series 18-21 where the antiplasmodial activity dramatically increases from methyl- (18: $22 \mu \mathrm{M})$ to mesityl-substituted (21: $0.21 \mathrm{nM})$ systems. By raising the sterically hindrance, the antimalarial activity was highly improved, reflecting an increase of the protective effect of the ligand around the metal and probably this allows to avoid releasing of the gold cation before reaching its target. 
Table 1. Antiplasmodial and cytotoxicity of imidazolium salts and their gold(I) $\mathrm{N}$ heterocyclic compounds.

\begin{tabular}{|c|c|c|c|}
\hline Compounds & $\begin{array}{c}\text { Antiplasmodial activity } \\
\mathrm{CI}_{50}(\boldsymbol{\mu M}) \text { on } P \text {. falciparum } *\end{array}$ & $\begin{array}{c}\text { Cytotoxicity activity } \\
\mathrm{CI}_{50}(\mu \mathrm{M}) \text { on Vero cell line }\end{array}$ & Selectivity index \\
\hline 1 & $17.9 \pm 1.3$ & & \\
\hline 2 & $1.4 \pm 0.2$ & $>140$ & $>100$ \\
\hline 3 & $1.5 \pm 0.1$ & $69.7 \pm 5.6$ & 46 \\
\hline 4 & $73.2 \pm 4.5^{\mathbb{I}}$ & & \\
\hline 5 & $>145^{\mathbb{I}}$ & & \\
\hline 6 & $>130^{\mathrm{II}}$ & & \\
\hline 7 & $59.6 \pm 1.4$ & & \\
\hline 8 & $11.3 \pm 0.6$ & & \\
\hline 9 & $6.4 \pm 0.1$ & & \\
\hline 10 & $>230$ & & \\
\hline 11 & $9.3 \pm 0.3$ & & \\
\hline $12^{\|}$ & $1.1 \pm 0.1$ & $<1^{\delta}$ & $<0.9$ \\
\hline 13 & $5.2 \pm 2.0$ & & \\
\hline 14 & $1.1 \pm 0.2$ & $6.6 \pm 0.4$ & 6 \\
\hline 15 & $0.47 \pm 0.1$ & $3.6 \pm 0.3$ & 8 \\
\hline $16^{\|}$ & $0.33 \pm 0.03$ & $1^{\delta}$ & 3 \\
\hline 17 & $6.6 \pm 0$ & & \\
\hline 18 & $22 \pm 3.8^{\mathbb{I}}$ & & \\
\hline 19 & $2.1 \pm 0.3^{\mathrm{I}}$ & & \\
\hline 20 & $0.48 \pm 0.06$ & $1.9 \pm 0$ & 4 \\
\hline 21 & $0.21 \pm 0.04$ & $3.7 \pm 0.1^{\S}$ & 18 \\
\hline
\end{tabular}




\begin{tabular}{|c|c|c|c|}
\hline $\mathbf{2 2}$ & $0.32 \pm 0.08$ & $3.6 \pm 0.7$ & 11 \\
\hline $\mathbf{2 3}$ & $4.1 \pm 0.4$ & & \\
\hline $\mathbf{2 4}$ & $5.6 \pm 0.8$ & & \\
\hline $\mathbf{2 5}$ & $3.7 \pm 0.7$ & $134 \pm 20$ & $717^{\mathbb{I}}$ \\
\hline Chloroquine $^{\#}$ & $0.514 \pm 0.02$ & & \\
\hline Artemisinin $^{\#}$ & $0.187 \pm 0.02^{\mathbb{I}}$ & ND & \\
\hline
\end{tabular}

* Antiplasmodial activity of the compounds were evaluated against the $P$. falciparum strain FcM29-Cameroon, except compounds noted ${ }^{(\mathbb{I})}$ evaluated against the $P$. falciparum strain FcB1-Columbia.

$\$$ Data represented the mean of 2 to 5 independent experiments.

" Reference 8c.

${ }^{\delta}$ Cytotoxicity activity of the compounds were evaluated against Vero cell lines, except compounds noted $\left({ }^{\delta}\right)$ evaluated on the McF7 line.

$\S$ Compound 21 was also tested against other cell lines and showed the following results: 0.4 $\mu \mathrm{M}$ (PC-3 cell line); $0.8 \mu \mathrm{M}$ (MCF-7 cell line); $0.8 \mu \mathrm{M}$ (U87 cell line); $0.9 \mu \mathrm{M}$ (A549 cell line); $1 \mu \mathrm{M}$ (Hep3B cell line); $>5 \mu \mathrm{M}$ (Huvec cell line). ${ }^{8 \mathrm{a}}$

\#Both antiplasmodial control drugs artemisinin and chloroquine were routinely tested.

We have previously reported that the selective cytotoxic activity of this family was directly correlated with the lipophilic properties ${ }^{8 a}$ and this trend is also verified here: the highest lipophilic complex $\mathbf{2 1}$ is the most active against $P$. falciparum. We can hypothesize that lipophilic properties could permit to compounds to better cross the different membranes (red blood cell membrane, parasitophorous vacuole membrane, parasite plasma membrane and eventually digestive vacuole membrane) to target the parasite. Concerning the aromatic nitrogen-containing $N$-functionalized NHC complexes 12, 14 and $\mathbf{1 5}$, the two quinoline moieties are positioned in trans-arrangement with respect to each other and thus provide already a good protection to the gold(I) center, in contrast to the previous complexes. That could also 
explain the less antiplasmodial activity with only one quinoline moiety (13:5.2 $\mu \mathrm{M})$. This feature can explain the same antiplasmodial activity for $\mathbf{1 2}(1.1 \mu \mathrm{M})$ and $\mathbf{1 4}(1.1 \mu \mathrm{M})$, differing in their non-functionalized substituents, methyl and mesityl, respectively. Introducing a second functionalized entity involving a thioether group (15) leads to an improvement of the antiproliferative activity with an $\mathrm{IC}_{50}$ of $0.47 \mu \mathrm{M}$. Moreover, it should be noted that the use of the methylthiophenyl group as the only functionalized group is also very interesting as evidenced by the antimalarial potency of complex $22\left(\mathrm{IC}_{50}=0.32 \mu \mathrm{M}\right)$.

Compounds 15, 16, 20, 21 and 22 showed thus very high antiplasmodial activity with IC $_{50}$ below the micromolar range. Compounds with the most promising antimalarial properties were also evaluated on culture cell lines in order to determine the specificity of their activity. The selectivity index are ranging from $<0.9$ to 18 . The best selectivity index was found with the compound 21. These results confirmed those already reported with various cell lines ${ }^{8 \mathrm{a}}$ with $\mathrm{IC}_{50}$ values below $1 \mu \mathrm{M}$ for all cancer cell lines tested whereas the value was superior to $5 \mu \mathrm{M}$ on non-tumor cells (primary cultures of human umbilical vein endothelial cells (HUVEC)). These data highlight that complex $\mathbf{2 1}$ is specifically active against pathogen cells such as $P$. falciparum or multiple cancer cell lines but shows restricted effects on normal human cells.

The potential of organometallic gold complexes without incorporation of known antimalarial organic drugs against parasitic diseases has been little explored until very recently. ${ }^{3,12}$ Messori and coll. used a panel of structurally diverse gold(I) and (III) complexes involving N, O or P heterocyclic ligands and the clinically established gold-based antiarthritic drug auranofin, to evaluate them as possible inhibitors of the parasite enzyme Falcipain 2 (Fp2) which is an important protease of $P$. falciparum and represents one of the most promising targets for antimalarial drug discovery. ${ }^{13}$ This protein is mainly involved in the degradation of host's hemoglobin (thus providing a substantial amount of peptides and amino acids to sustain parasite growth) and its proteolytic activity is more pronounced at the early trophozoite stage of parasite 
development. Remarkably, most tested gold compounds caused pronounced but reversible inhibition of Fp2 and important parasite growth inhibition of $P$. falciparum was observed in vitro. However, any direct correlation between enzyme inhibition and reduction of $P$. falciparum growth was established, suggesting that Fp2 inhibition represents just one of the various mechanisms through which gold compounds effectively antagonize $P$. falciparum replication. Chibale and coll. reported gold(I) and gold(III) thiosemicarbazone (TSCs) compounds which exhibit moderate in vitro activity against two P. falciparum strains, CQsensitive D10 $\left(\mathrm{IC}_{50}\right.$ of $\left.\mathrm{CQ}=0.0173 \mu \mathrm{M}\right)$ and CQ-resistant $\mathrm{W} 2\left(\mathrm{IC}_{50}\right.$ of $\left.\mathrm{CQ}=0.095 \mu \mathrm{M}\right)$ with $\mathrm{IC}_{50}$ ranging from 1.36 to $6.92 \mu \mathrm{M}$ for the gold(I) compounds and $\mathrm{IC}_{50}$ ranging from 3.04 to > $20 \mu \mathrm{M}$ for the gold(III) complexes; the gold(I) TSCs complexes also inhibit the Fp2 but no correlation was found between their antiplasmodial activity and the ability to inhibit Fp2. ${ }^{14}$ Mohr and coll. reported gold(I) complexes involving functionalized alkynes that have shown low in vitro activity against falciparum malaria parasite strains CQ-sensitive 3D7 (IC50 of CQ $=0.01 \mu \mathrm{M})$ and CQ-resistant $\mathrm{K} 1\left(\mathrm{IC}_{50}\right.$ of $\left.\mathrm{CQ}=0.3 \mu \mathrm{M}\right)$ with $\mathrm{IC}_{50}$ values between 7.2 and 23 $\mu \mathrm{M} .{ }^{15}$ The same authors described also a series of mono- and dinuclear gold(I) phosphine complexes containing mono-anionic seleno- and thiosemicarbazones ligands; the $\mathrm{IC}_{50}$ results showed that two sulfur containing mononuclear compounds exhibit activity similar to CQ against the 3D7 strain with $\mathrm{IC}_{50}$ of 7.06 and $10.7 \mathrm{nM}\left(\mathrm{IC}_{50}\right.$ of $\left.\mathrm{CQ}=8.84 \mathrm{nM}\right) .{ }^{16}$ Unfortunately, neither the $\mathrm{IC}_{50}$ of the thiosemicarbazones ligands nor the toxicity of the corresponding complexes were evaluated. Previous studies realized by C. Lambros and co-workers revealed that the two involved ligands themselves already exhibit high in vitro antimalarial activity (CQresistant $P$. falciparum Smith strain with $\mathrm{ID}_{50}$ below $10 \mathrm{ng} / \mathrm{mL}$ (ID50 of CQ $=60 \mathrm{ng} / \mathrm{mL}$ ) and moreover they are toxic in vivo (on P. berghei at doses $>20$ or $40 \mathrm{mg} / \mathrm{kg}$ ). ${ }^{17}$ Cronje and coll. reported preliminary in vitro antimalarial activities of $N$-heterocyclic ylideneamine gold(I) against $P$. falciparum; the coordination of ancillary phosphine or NHC ligands to these 
complexes results in better activities with an $\mathrm{IC}_{50}$ value of $5.1 \mu \mathrm{g} / \mathrm{ml}$ for the NHC derivative. ${ }^{18}$ In light of the available literature concerning gold compounds, some of our $\mathrm{Au}(\mathrm{I})-\mathrm{NHC}$ complexes display improved efficacy.

\section{Conclusion}

In summary, a series of $\mathrm{N}-, \mathrm{O}$ - or $\mathrm{S}$-functionalized proligands and their corresponding mononuclear cationic, anionic or neutral gold(I) bisNHC complexes, including eight new fully characterized compounds, were tested in vitro for their antimalarial potency against chloroquine-resistant $P$. falciparum strains. Moreover, cytotoxicity of the most active compounds was assessed on Vero cell line, in order to determine their selectivity of action. From this screening, the importance of the charge of the molecules tested in the antiplasmodial activity was observed. Cationic lipophilic gold(I)-NHC complexes are more active than similar neutral and anionic complexes. Moreover, an active complex has to be highly lipophilic and the presence of nitrogen or sulphur atoms in the ligands seems to have a positive influence on the antiplasmodial activity.

The pharmaco-modulation, by fine tuning either the global charge of the complexes and the key substituents on the NHC ligands, permitted to increase the antiplasmodial activity with promising selectivity indexes and highlighted the interest for gold cationic compounds which can be considered as a good scaffold for the optimisation of a new antimalarial chemistry.

\section{Experimental}

\subsection{Chemistry}




\subsubsection{General methods}

All manipulations were performed under an inert atmosphere of dry nitrogen by using standard vacuum line and Schlenk tube techniques. 3-Methyl-1-\{[6-(pyridin-2-yl)pyridin-3yl]methyl $\}-1 H$-imidazol-3-ium bromide (4H), $\mathrm{Ag}(\mathbf{4})_{2} \mathrm{Br}^{8 \mathrm{c}}$ and 1-(4-methylthiophenyl)-1Himidazole $^{8 \mathrm{~d}}$ were synthetized according to literature procedures. All reagents were used as received from commercial suppliers. Reactions involving silver compounds were performed with the exclusion of the light. ${ }^{1} \mathrm{H}\left(300\right.$ or $400 \mathrm{MHz}$ ) and ${ }^{13} \mathrm{C}$ NMR spectra (75 or $101 \mathrm{MHz}$ ) were recorded at $298 \mathrm{~K}$ on Bruker AV300 or Bruker AV400 spectrometers in $\mathrm{CDCl}_{3}, \mathrm{CD}_{3} \mathrm{CN}$, DMSO- $d_{6}$ and $\mathrm{D}_{2} \mathrm{O}$ as solvents. Elemental analyses were carried out by the "Service de Microanalyse du Laboratoire de Chimie de Coordination (Toulouse). High Resolution Mass Spectrometry (HRMS) analysis were performed with a Thermo Finnigan MAT 95 XL spectrometer using electrospray ionization (ESI) or with a TOF mass analyzer by desorption chemical ionization with methane gas (DCI) by the "Service de Spectrométrie de Masse de Chimie UPS-CNRS" (Toulouse).
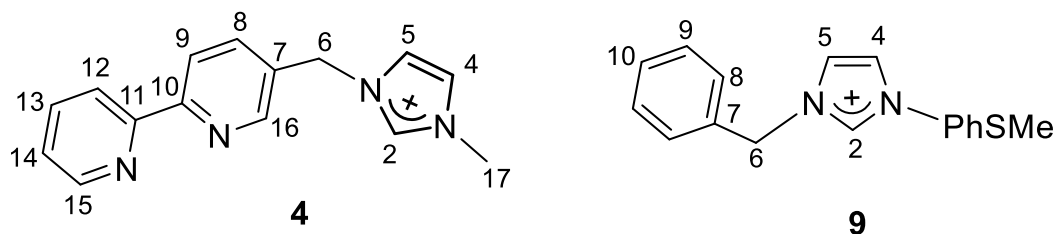

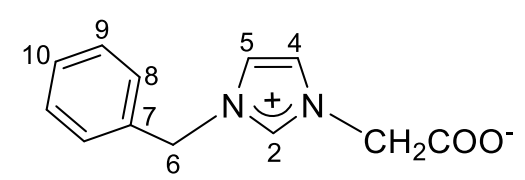

10

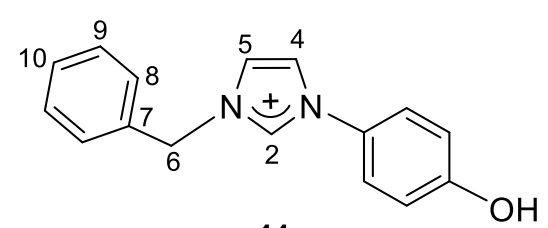

11

Numbering of $\mathrm{H}\left({ }^{1} \mathrm{H}\right.$ NMR $)$ and $\mathrm{C}\left({ }^{13} \mathrm{C}\right.$ NMR $)$. These notations are used in the following section.

\subsubsection{1-(4-Methylthiophenyl)-3-benzylimidazolium chloride (9)}

1-(4-Methylthiophenyl)-1H-imidazole (1.00 g, $5.26 \mathrm{mmol})$, benzylchloride (605 $\mu \mathrm{L}, 5.26$ mmol) and $\mathrm{KPF}_{6}(967 \mathrm{mg}, 5.26 \mathrm{mmol})$ were stirred in $\mathrm{CH}_{3} \mathrm{CN}(20 \mathrm{~mL})$ at $80{ }^{\circ} \mathrm{C}$ for 3 days. 
After cooling to room temperature, the solvent was evaporated and the yellow solid obtained was washed with $\mathrm{CH}_{2} \mathrm{Cl}_{2}$ and diethyl ether and dried under vacuum (2.018 g, 90\% yield). Anal. Calcd. For $\mathrm{C}_{17} \mathrm{H}_{17} \mathrm{~N}_{2} \mathrm{SPF}_{6}$ : C, 47.89; H, 4.02; N, 6.57. Found: C, 47.93; H, 4.06; N, 6.55. ${ }^{1} \mathrm{H}$ NMR (400 MHz, DMSO-d $) \delta 10.44\left(\mathrm{~s}, 1 \mathrm{H}, H_{2}\right), 8.38\left(\mathrm{~d}, J=1.6 \mathrm{~Hz}, 1 \mathrm{H}, H_{5}\right), 8.11(\mathrm{~d}, J=1.6$ $\left.\mathrm{Hz}, 1 \mathrm{H}, H_{4}\right), 7.79\left(\mathrm{~d}, J=8.6 \mathrm{~Hz}, 2 \mathrm{H}, H_{P h S M e}\right), 7.99\left(\mathrm{~d}, J=6.6 \mathrm{~Hz}, 2 \mathrm{H}, H_{8}\right), 7.49$ (d, $J=8.6 \mathrm{~Hz}$, 2H, $\left.H_{\text {PhSMe }}\right), 7.45-7.37\left(\mathrm{~m}, 3 \mathrm{H}, H_{9}, H_{10}\right), 5.57\left(\mathrm{~s}, 2 \mathrm{H}, H_{6}\right), 2.54\left(\mathrm{~s}, 3 \mathrm{H}, H_{\text {PhSMe }}\right) .{ }^{13} \mathrm{C}$ NMR $(75$ MHz, DMSO-d $\left.d_{6}\right) \delta 141.37$ (1C, $C_{\text {PhSMe }}$ ), 135.73 (1C, $\left.C_{2}\right), 134.79\left(1 \mathrm{C}, C_{7}\right), 131.93$ (1C, $\left.C_{P h S M e}\right)$, $129.47\left(2 \mathrm{C}, C_{9}\right), 129.34\left(1 \mathrm{C}, C_{10}\right), 128.95$ (2C, $\left.C_{8}\right), 127.09$ (2C, $\left.C_{P h S M e}\right), 123.58\left(1 \mathrm{C}, C_{5}\right)$, 122.86 (2C, $\left.C_{\text {PhSMe }}\right), 122.12\left(1 \mathrm{C}, C_{4}\right), 52.93$ (1C, $\left.C_{6}\right), 14.92\left(1 \mathrm{C}, C_{P h S M e}\right) . \mathrm{HRMS}\left(\mathrm{ES}^{+}\right)$ calculated for $\mathrm{C}_{17} \mathrm{H}_{17} \mathrm{~N}_{2} \mathrm{~S}\left(\mathrm{M}-\mathrm{PF}_{6}\right)^{+}$281.1112, found 281.1120 .

\subsubsection{1-(Carboxymethyl)-3-benzylimidazolium (10)}

Benzylimidazole (419 mg, $2.65 \mathrm{mmol})$ and bromoacetic acid (368 mg, $2.65 \mathrm{mmol})$ were heated at $130{ }^{\circ} \mathrm{C}$ for $24 \mathrm{~h}$. After the mixture was cooled to room temperature, the oily product was dissolved in $20 \mathrm{ml} \mathrm{H} \mathrm{H}_{2} \mathrm{O}$ and $\mathrm{Na}_{2} \mathrm{CO}_{3}$ was added $(281 \mathrm{mg}, 2.65 \mathrm{mmol})$. The mixture was refluxed at $100{ }^{\circ} \mathrm{C}$ for $30 \mathrm{~min}$. After evaporation of the solvent, the resulting solid was partially dissolved in $\mathrm{MeOH}$, filtered and the filtrate was evaporated to dryness. The crude product was washed with $\mathrm{CH}_{2} \mathrm{Cl}_{2}$ and dried under vacuum to afford a white solid ( $0.44 \mathrm{~g}, 77 \%$ yield). Anal. Calcd. For $\mathrm{C}_{12} \mathrm{H}_{12} \mathrm{~N}_{2} \mathrm{O}_{2}$ : C, 66.65; H, 5.59; N, 12.96. Found: C, 66.58; H, 5.66; N, 12.90. ${ }^{1} \mathrm{H}$ NMR (300 MHz, DMSO-d $\left.d_{6}\right) \delta 9.21\left(\mathrm{~s}, 1 \mathrm{H}, H_{2}\right), 7.69\left(\mathrm{~s}, 1 \mathrm{H}, H_{5}\right), 7.60\left(\mathrm{~s}, 1 \mathrm{H}, H_{4}\right), 7.40(\mathrm{~m}, 5 \mathrm{H}$, $\left.H_{8}, H_{9}, H_{10}\right), 5.43\left(\mathrm{~s}, 2 \mathrm{H}, H_{6}\right), 4.45\left(\mathrm{~s}, 2 \mathrm{H}, H_{\mathrm{CH} 2 \mathrm{COO}}\right) .{ }^{13} \mathrm{C} \mathrm{NMR}\left(75 \mathrm{MHz}, \mathrm{D}_{2} \mathrm{O}\right) \delta 172.10(1 \mathrm{C}$,

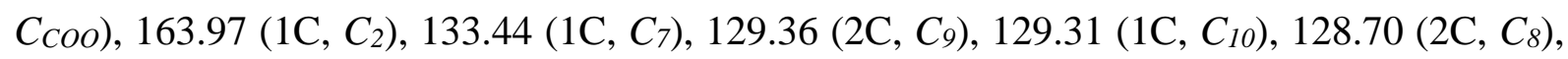
$123.71\left(1 \mathrm{C}, C_{5}\right), 121.94\left(1 \mathrm{C}, C_{4}\right), 52.89\left(1 \mathrm{C}, C_{6}\right), 52.01\left(1 \mathrm{C}, C_{C H 2 C O O}\right) . \mathrm{HRMS}\left(\mathrm{ES}^{+}\right)$calculated for $\mathrm{C}_{12} \mathrm{H}_{13} \mathrm{~N}_{2} \mathrm{O}_{2}(\mathrm{M}+\mathrm{H})^{+} 217.0977$, found 217.0978. 


\subsubsection{1-(4-Hydroxyphenyl)-3-benzylimidazolium hexafluorophosphate (11)}

1-(4-Hydroxyphenyl)imidazole (1.642 g, $9.760 \mathrm{mmol})$, benzylchloride $(1.15 \mathrm{~mL}, 9.760$ $\mathrm{mmol})$ and $\mathrm{KPF}_{6}(1.800 \mathrm{~g}, 9.760 \mathrm{mmol})$ were heated in acetonitrile $(20 \mathrm{~mL})$ at $80{ }^{\circ} \mathrm{C}$ for 3 days. The white solid obtained was filtered and dried under vacuum (3.595 g, 93\% yield). Anal. Calcd. For $\mathrm{C}_{16} \mathrm{H}_{15} \mathrm{~N}_{2} \mathrm{OPF}_{6}$ : C, 48.50; H, 3.82; N, 7.07. Found: C, 48.47; H, 3.95; N, 7.01. ${ }^{1} \mathrm{H}$ NMR (300 MHz, DMSO-d $) \delta 10.31\left(\mathrm{~s}, 1 \mathrm{H}, H_{P h O H}\right), 9.74\left(\mathrm{t}, J=1.8 \mathrm{~Hz}, 1 \mathrm{H}, H_{2}\right), 8.11(\mathrm{t}, J=$ $\left.1.9 \mathrm{~Hz}, 1 \mathrm{H}, H_{5}\right), 7.90\left(\mathrm{t}, J=1.9 \mathrm{~Hz}, 1 \mathrm{H}, H_{4}\right), 7.56\left(\mathrm{~d}, J=8.9 \mathrm{~Hz}, 2 \mathrm{H}, H_{P h O H}\right), 7.53-7.36(\mathrm{~m}$, $\left.5 \mathrm{H}, H_{8}, H_{9}, H_{10}\right), 6.98\left(\mathrm{~d}, J=8.9 \mathrm{~Hz}, 2 \mathrm{H}, H_{P h O H}\right), 5.47\left(\mathrm{~s}, 2 \mathrm{H}, H_{6}\right) .{ }^{13} \mathrm{C}$ NMR $(75 \mathrm{MHz}, \mathrm{DMSO}-$ d6) $\delta 159.09\left(1 \mathrm{C}, C_{\mathrm{PhOH}}\right), 135.58\left(1 \mathrm{C}, C_{2}\right), 135.01\left(1 \mathrm{C}, C_{7}\right), 129.49\left(2 \mathrm{C}, C_{9}\right), 129.32\left(1 \mathrm{C}, C_{10}\right)$, 128.89 (2C, $\left.C_{8}\right), 126.94\left(1 \mathrm{C}, C_{P h O H}\right), 124.23$ (2C, $\left.C_{P h O H}\right), 123.43\left(1 \mathrm{C}, C_{5}\right), 122.52\left(1 \mathrm{C}, C_{4}\right)$, $116.74\left(2 \mathrm{C}, C_{P h O H}\right), 52.83\left(1 \mathrm{C}, C_{6}\right)$. HRMS $\left(\mathrm{ES}^{+}\right)$calculated for $\mathrm{C}_{16} \mathrm{H}_{15} \mathrm{~N}_{2} \mathrm{O}\left(\mathrm{M}-\mathrm{PF}_{6}\right)^{+}$ 251.1184, found 251.1189.

\subsection{5. $\{1-[([2,2$ '-Bipyridin]-5-yl)methyl]-3-methylimidazol-2-ylidene $\}($ chloro)gold(I) (17)}

Complex 17 was obtained by transmetalation of $\operatorname{Ag}(4)_{2} \mathrm{Br}(81 \mathrm{mg}, 0.118 \mathrm{mmol})$ with $\mathrm{Au}\left(\mathrm{SMe}_{2}\right) \mathrm{Cl}(69.2 \mathrm{mg}, 0.235 \mathrm{mmol})$ in a mixture of $\mathrm{CH}_{2} \mathrm{Cl}_{2}-\mathrm{MeOH}(4 \mathrm{~mL} / 2 \mathrm{~mL})$ at r.t.. After stirring for $1 \mathrm{~h}$, the solution was filtered through a pad of celite and the solvent removed under reduced pressure to give a grey solid (0.72 g, 63\% yield). Anal. Calcd. For $\mathrm{C}_{15} \mathrm{H}_{14} \mathrm{~N}_{4} \mathrm{AuCl}$ : C, 37.32; H, 2.92; N, 11.61. Found: C, 37.27; H, 3.06; N, 11.57. ${ }^{1} \mathrm{H}$ NMR (400 MHz, $\left.\mathrm{CDCl}_{3}\right) \delta$ $8.73-8.67\left(\mathrm{~m}, 2 \mathrm{H}, H_{15}, H_{16}\right), 8.48\left(\mathrm{~d}, J=8.2 \mathrm{~Hz}, 1 \mathrm{H}, H_{12}\right), 8.43\left(\mathrm{~d}, J=8.0 \mathrm{~Hz}, 1 \mathrm{H}, H_{9}\right), 7.95-$ $7.80\left(\mathrm{~m}, 2 \mathrm{H}, H_{8}, H_{13}\right), 7.39\left(\mathrm{ddd}, J=7.5,4.8,1.1 \mathrm{~Hz}, 1 \mathrm{H}, H_{14}\right), 7.00\left(\mathrm{~d}, J=1.9 \mathrm{~Hz}, 1 \mathrm{H}, H_{5}\right)$, $6.96\left(\mathrm{~d}, J=1.9 \mathrm{~Hz}, 1 \mathrm{H}, H_{4}\right), 5.49\left(\mathrm{~s}, 2 \mathrm{H}, H_{6}\right), 3.90\left(\mathrm{~s}, 3 \mathrm{H}, H_{17}\right) .{ }^{13} \mathrm{C} \mathrm{NMR}\left(101 \mathrm{MHz}, \mathrm{CDCl}_{3}\right)$ $\delta 171.99\left(1 \mathrm{C}, C_{2}\right), 156.78\left(1 \mathrm{C}, C_{10}\right), 155.25\left(1 \mathrm{C}, C_{11}\right), 149.25\left(1 \mathrm{C}, C_{15}\right), 148.50\left(1 \mathrm{C}, C_{16}\right)$, $137.05\left(1 \mathrm{C}, C_{13}\right), 136.68\left(1 \mathrm{C}, C_{8}\right), 130.61\left(1 \mathrm{C}, C_{7}\right), 124.11\left(1 \mathrm{C}, C_{14}\right), 122.70\left(1 \mathrm{C}, C_{5}\right), 121.31$ 
$\left(1 \mathrm{C}, C_{9}\right), 121.25\left(1 \mathrm{C}, C_{12}\right), 120.21\left(1 \mathrm{C}, C_{4}\right), 52.41\left(1 \mathrm{C}, C_{6}\right), 38.41\left(1 \mathrm{C}, C_{17}\right) . \mathrm{HRMS}\left(\mathrm{ES}^{+}\right)$ calculated for $\mathrm{C}_{15} \mathrm{H}_{14} \mathrm{~N}_{4} \mathrm{Au}(\mathrm{M}-\mathrm{Cl})^{+} 447.0884$, found 447.0887 .

\subsection{6.}

\section{Bis\{1-benzyl-3-[4-(methylsulfanyl)phenyl]imidazol-2-ylidene\}gold(I)}

\section{hexafluorophosphate (22)}

Under a nitrogen atmosphere, sodium acetate $(69.3 \mathrm{mg}, 0.844 \mathrm{mmol})$ was added to a mixture of $9(300 \mathrm{mg}, 0.704 \mathrm{mmol})$ and $\mathrm{Au}\left(\mathrm{SMe}_{2}\right) \mathrm{Cl}(104 \mathrm{mg}, 0.352 \mathrm{mmol})$ in dry DMF $(6 \mathrm{~mL})$ at $100^{\circ} \mathrm{C}$. The mixture was then heated to $120^{\circ} \mathrm{C}$ and this temperature was maintained for $2 \mathrm{~h}$. After cooling to room temperature, the solution was filtered through a pad of celite and the solvent removed under reduced pressure to give a white solid $(0.277 \mathrm{~g}, 87 \%$ yield $)$. Anal. Calcd. For $\mathrm{C}_{34} \mathrm{H}_{32} \mathrm{~N}_{4} \mathrm{~S}_{2} \mathrm{PF}_{6} \mathrm{Au}$ : C, 45.24; H, 3.57; N, 6.21. Found: $\mathrm{C}, 45.29 ; \mathrm{H}, 3.62 ; \mathrm{N}, 6.24 .{ }^{1} \mathrm{H}$ NMR $\left(300 \mathrm{MHz}, \mathrm{DMSO}-d_{6}\right) \delta 7.88\left(\mathrm{~d}, J=1.9 \mathrm{~Hz}, 2 \mathrm{H}, H_{5}\right), 7.82\left(\mathrm{~d}, J=1.9 \mathrm{~Hz}, 2 \mathrm{H}, H_{4}\right), 7.63(\mathrm{~d}, 4 \mathrm{H}$, $\left.J=8.6 \mathrm{~Hz}, H_{P h S M e}\right), 7.37-7.28\left(\mathrm{~m}, 6 \mathrm{H}, H_{9}, H_{10}\right), 7.26\left(\mathrm{~d}, 4 \mathrm{H}, J=8.6 \mathrm{~Hz}, H_{P h S M e}\right), 7.24-7.17$ $\left(\mathrm{m}, 4 \mathrm{H}, H_{8}\right), 5.35\left(\mathrm{~s}, 4 \mathrm{H}, H_{6}\right), 2.45\left(\mathrm{~s}, 6 \mathrm{H}, H_{P h S M e}\right) .{ }^{13} \mathrm{C}$ NMR $\left(75 \mathrm{MHz}, \mathrm{DMSO}-d_{6}\right) \delta 181.57$ (2C, $\left.C_{2}\right), 140.26$ (2C, $\left.C_{P h S M e}\right), 136.62$ (2C, $\left.C_{7}\right), 135.92$ (2C, $\left.C_{P h S M e}\right), 129.21$ (4C, C9), 128.66 (2C, $\left.C_{10}\right), 127.94$ (4C $\left.C_{8}\right), 126.64$ (4C, $\left.C_{P h S M e}\right), 125.71$ (4C, $\left.C_{P h S M e}\right), 123.93\left(2 \mathrm{C}, C_{5}\right), 123.61$ $\left(2 \mathrm{C}, C_{4}\right), 54.35\left(2 \mathrm{C}, C_{6}\right), 14.95\left(2 \mathrm{C}, C_{P h S M e}\right) . \mathrm{HRMS}\left(\mathrm{ES}^{+}\right)$calculated for $\mathrm{C}_{34} \mathrm{H}_{32} \mathrm{~N}_{4} \mathrm{~S}_{2} \mathrm{Au}(\mathrm{M}-$ $\left.\mathrm{PF}_{6}\right)^{+}$757.1734, found 757.1744 .

\subsection{7. \{1-Benzyl-3-[4-(methylsulfanyl)phenyl]imidazol-2-ylidene\}(chloro)gold(I) (23)}

Under a nitrogen atmosphere and protection of the light, a Schlenk tube was charged with 9 (261 mg, $0.612 \mathrm{mmol}$ ) in a mixture of $\mathrm{CH}_{2} \mathrm{Cl}_{2}-\mathrm{MeOH}(5 \mathrm{~mL} / 1 \mathrm{~mL}), \mathrm{Ag}_{2} \mathrm{O}(71 \mathrm{mg}, 0.306$ $\mathrm{mmol})$ and $\mathrm{KCl}(68 \mathrm{mg}, 0.918 \mathrm{mmol})$. The reaction mixture was stirred at r.t. for $6 \mathrm{~h}$. After that $\mathrm{Au}\left(\mathrm{SMe}_{2}\right) \mathrm{Cl}(180 \mathrm{mg}, 0.612 \mathrm{mmol})$ was added and the mixture was stirred for $4 \mathrm{~h}$. The solution was filtered through a pad of celite and the solvent removed under reduced pressure to give a 
grey solid (0.267 g, 82\% yield). Anal. Calcd. For $\mathrm{C}_{17} \mathrm{H}_{16} \mathrm{~N}_{2} \mathrm{SClAu}$ : C, 39.82; H, 3.15; N, 5.46. Found: C, 39.76; H, 3.22; N, 5.48. ${ }^{1} \mathrm{H}$ NMR $\left(300 \mathrm{MHz}, \mathrm{CD}_{3} \mathrm{CN}\right) \delta 7.63(\mathrm{~d}, J=8.8 \mathrm{~Hz}, 2 \mathrm{H}$, $\left.H_{P h S M e}\right), 7.48-7.38\left(\mathrm{~m}, 8 \mathrm{H}, H_{P h S M e}, H_{5}, H_{8}, H_{9}, H_{10}\right), 7.36\left(\mathrm{~d}, J=2.0 \mathrm{~Hz}, 1 \mathrm{H}, H_{4}\right), 5.48(\mathrm{~s}, 2 \mathrm{H}$, $\left.H_{6}\right), 2.56\left(\mathrm{~s}, 3 \mathrm{H}, H_{P h S M e}\right) .{ }^{13} \mathrm{C}$ NMR $\left(75 \mathrm{MHz}, \mathrm{DMSO}-d_{6}\right) \delta 168.90\left(1 \mathrm{C}, C_{2}\right), 140.10(1 \mathrm{C}$, $C_{\text {PhSMe }}$ ), 136.84 (1C, $\left.C_{7}\right), 136.18$ (1C, $\left.C_{\text {PhSMe }}\right), 129.30$ (2C, $\left.C_{9}\right), 128.69\left(1 \mathrm{C}, C_{10}\right), 128.23$ (2C, $\left.C_{8}\right), 126.73\left(2 \mathrm{C}, C_{P h S M e}\right), 125.93\left(2 \mathrm{C}, C_{P h S M e}\right), 123.57\left(1 \mathrm{C}, C_{5}\right), 123.01\left(1 \mathrm{C}, C_{4}\right), 54.62\left(1 \mathrm{C}, C_{6}\right)$, $15.00\left(1 \mathrm{C}, C_{P h S M e}\right)$. HRMS (DCI) calculated for $\mathrm{C}_{17} \mathrm{H}_{16} \mathrm{~N}_{2} \mathrm{SAu}(\mathrm{M}-\mathrm{Cl})^{+} 477.0700$, found 477.0710.

\subsubsection{Hydrogen bis[1-benzyl-3-(carboxylatomethyl)imidazol-2-ylidene]gold(I) (24)}

Under a nitrogen atmosphere and protection of the light, a Schlenk tube was charged with 10 (338 mg, $1.563 \mathrm{mmol})$ in $10 \mathrm{ml}$ of dry $\mathrm{MeOH}$ and $\mathrm{Ag}_{2} \mathrm{O}(181 \mathrm{mg}, 0.782 \mathrm{mmol})$. The mixture was stirred for $12 \mathrm{~h}$ at $50{ }^{\circ} \mathrm{C}$. After cooling to r.t., $\mathrm{Au}\left(\mathrm{SMe}_{2}\right) \mathrm{Cl}(230 \mathrm{mg}, 0.782 \mathrm{mmol})$ was added and the mixture was stirred at r.t. for $2 \mathrm{~h}$. The solution was filtered through a pad of celite and the solvent removed under reduced pressure to give a grey solid ( $0.407 \mathrm{~g}, 83 \%$ yield). Anal. Calcd. For $\mathrm{C}_{24} \mathrm{H}_{23} \mathrm{~N}_{4} \mathrm{O}_{4} \mathrm{Au}$ : C, 45.87; H, 3.69; N, 8.92. Found: C, 45.90; H, 3.90; N, 8.93. ${ }^{1} \mathrm{H}$ NMR (300 MHz, DMSO- $\left.d_{6}\right) \delta 7.45\left(\mathrm{~s}, 2 \mathrm{H}, H_{5}\right), 7.39-7.28\left(\mathrm{~m}, 12 \mathrm{H}, H_{4}, H_{8}, H_{9}, H_{10}\right), 5.32(\mathrm{~s}$, $\left.4 \mathrm{H}, H_{6}\right), 4.50\left(\mathrm{~s}, 2 \mathrm{H}, H_{\mathrm{CH} 2 \mathrm{COO}}\right), 4.42\left(\mathrm{~s}, 2 \mathrm{H}, \mathrm{H}_{\mathrm{CH} 2 \mathrm{COO}}\right) .{ }^{13} \mathrm{C} \mathrm{NMR}\left(75 \mathrm{MHz}, \mathrm{D}_{2} \mathrm{O}\right) \delta 184.51(2 \mathrm{C}$, $\left.C_{2}\right), 174.02\left(2 \mathrm{C}, C_{C O O}\right), 136.53\left(2 \mathrm{C}, C_{7}\right), 128.83\left(4 \mathrm{C}, C_{9}\right), 128.15\left(2 \mathrm{C}, C_{10}\right), 127.40\left(4 \mathrm{C}, C_{8}\right)$, $123.05\left(2 \mathrm{C}, C_{5}\right), 121.74\left(2 \mathrm{C}, C_{4}\right), 53.91\left(2 \mathrm{C}, C_{6}\right), 53.85\left(2 \mathrm{C}, C_{C H 2 C O O}\right)$. HRMS $\left(\mathrm{ES}^{+}\right)$calculated for $\mathrm{C}_{24} \mathrm{H}_{24} \mathrm{~N}_{4} \mathrm{O}_{4} \mathrm{Au}(\mathrm{M}+\mathrm{H})^{+}$629.1463, found 629.1478 .

\subsubsection{Hydrogen bis\{1-benzyl-3-[(4-oxidophenyl)]imidazol-2-ylidene\}gold(I) (25)}

Under a nitrogen atmosphere, sodium acetate $(74.5 \mathrm{mg}, 0.908 \mathrm{mmol})$ was added to a mixture of $11(300 \mathrm{mg}, 0.757 \mathrm{mmol})$ and $\mathrm{Au}\left(\mathrm{SMe}_{2}\right) \mathrm{Cl}(112 \mathrm{mg}, 0.379 \mathrm{mmol})$ in dry DMF (5 mL) at 
$100{ }^{\circ} \mathrm{C}$. The mixture was then heated to $120^{\circ} \mathrm{C}$ and this temperature was maintained for $2 \mathrm{~h}$. After cooling to room temperature, $\mathrm{CH}_{2} \mathrm{Cl}_{2}(5 \mathrm{~mL})$ and hexane $(10 \mathrm{~mL})$ were added to the solution to afford a beige solid, which was filtered and dried under vacuum $(0.175 \mathrm{~g}, 66 \%$ yield). Anal. Calcd. For $\mathrm{C}_{32} \mathrm{H}_{27} \mathrm{~N}_{4} \mathrm{O}_{2} \mathrm{Au}$ : C, 55.18; H, 3.91; N, 8.04. Found: C, 55.23; H, 3.96; N, 8.10. ${ }^{1} \mathrm{H}$ NMR $\left(400 \mathrm{MHz}, \mathrm{DMSO}-d_{6}\right) \delta 7.77-7.76\left(\mathrm{~m}, 4 \mathrm{H}, H_{4}, H_{5}\right), 7.37(\mathrm{~d}, J=8.8 \mathrm{~Hz}, 4 \mathrm{H}$, $\left.H_{P h O}\right), 7.31-7.29\left(\mathrm{~m}, 6 \mathrm{H}, H_{9}, H_{10}\right), 7.19\left(\mathrm{dd}, J=6.7,2.9 \mathrm{~Hz}, 4 \mathrm{H}, H_{8}\right), 6.82(\mathrm{~d}, J=8.8 \mathrm{~Hz}, 4 \mathrm{H}$, $\left.H_{P h o}\right), 5.31\left(\mathrm{~s}, 4 \mathrm{H}, H_{6}\right) .{ }^{13} \mathrm{C} \mathrm{NMR}(101 \mathrm{MHz}, \mathrm{DMSO}) \delta 181.55\left(2 \mathrm{C}, C_{2}\right), 158.36\left(2 \mathrm{C}, C_{P h o}\right)$, $136.66\left(2 \mathrm{C}, C_{7}\right), 130.71\left(2 \mathrm{C}, C_{P h O}\right), 129.22\left(4 \mathrm{C}, C_{9}\right), 128.69\left(2 \mathrm{C}, C_{10}\right), 127.94\left(4 \mathrm{C}, C_{8}\right), 126.43$ (4C, $\left.C_{P h O}\right), 123.88\left(2 \mathrm{C}, C_{5}\right), 123.12\left(2 \mathrm{C}, C_{4}\right), 116.24\left(4 \mathrm{C}, C_{P h O}\right), 54.19\left(2 \mathrm{C}, C_{6}\right) . \mathrm{HRMS}\left(\mathrm{ES}^{+}\right)$ calculated for $\mathrm{C}_{32} \mathrm{H}_{28} \mathrm{~N}_{4} \mathrm{O}_{2} \mathrm{Au}(\mathrm{M}+\mathrm{H})^{+}$697.1878, found 697.1874.

\subsection{Crystallographic data for 17,22 and 23}

All data were collected at low temperature using oil-coated shock-cooled crystals on a Bruker-AXS APEX II diffractometer with MoK $\alpha$ radiation $(\lambda=0.71073 \AA)$. The structures were solved by direct methods ${ }^{19}$ and all non hydrogen atoms were refined anisotropically using the least-squares method on $F^{2}$., 20

CCDC-1441512 (17), CCDC-1441513 (22) and CCDC-1441514 (23) contain the supplementary crystallographic data. These data can be obtained free of charge from The Cambridge Crystallographic Data Centre via www.ccdc.cam.ac.uk/data_request/cif.

17: $\mathrm{C}_{15} \mathrm{H}_{14} \mathrm{AuClN}_{4}, \mathrm{Mr}=482.72$, crystal size $=0.30 \times 0.30 \times 0.10 \mathrm{~mm}^{3}$, monoclinic, space group $P 2_{1} / c, a=5.6934(3) \AA, b=11.8070(6) \AA, c=21.8435(12) \AA, \beta=92.646(3)^{\circ}, \mathrm{V}=$ 1466.8(2) $\AA^{3}, \mathrm{Z}=4, \mathrm{~T}=173(2) \mathrm{K}, 2506$ unique reflections, $\mathrm{R} 1=0.0554, \mathrm{wR} 2=0.1535$ $[\mathrm{I}>2 \sigma(\mathrm{I})], \mathrm{R} 1=0.0759, \mathrm{wR} 2=0.1659$ (all data), residual electron density $=2.400 \mathrm{e} \AA^{-3}$. 
22: $\mathrm{C}_{34} \mathrm{H}_{32} \mathrm{AuF}_{6} \mathrm{~N}_{4} \mathrm{PS}_{2}, \mathrm{Mr}=902.69$, crystal size $=0.30 \times 0.30 \times 0.10 \mathrm{~mm}^{3}$, monoclinic, space group $P 2_{1} / n, a=11.7142(5) \AA, b=11.6965(5) \AA, c=12.7877(6) \AA, \beta=108.408(1)^{\circ}, \mathrm{V}=$ 1662.5(2) $\AA^{3}, Z=2, T=173(2) \mathrm{K}, 24252$ reflections collected, 6058 unique reflections $\left(\mathrm{R}_{\text {int }}=\right.$ 0.0409), $\mathrm{R} 1=0.0228, \mathrm{wR} 2=0.0551[\mathrm{I}>2 \sigma(\mathrm{I})], \mathrm{R} 1=0.0324, \mathrm{wR} 2=0.0613$ (all data), residual electron density $=1.811 \mathrm{e} \AA^{-3}$.

23: $\mathrm{C}_{17} \mathrm{H}_{16} \mathrm{AuClN}_{2} \mathrm{~S}, \mathrm{Mr}=512.79$, crystal size $=0.30 \times 0.20 \times 0.05 \mathrm{~mm}^{3}$, triclinic, space group $P \overline{1}, a=9.545(1) \AA, b=9.931(1) \AA, c=10.044(1) \AA, \alpha=103.547(4)^{\circ}, \beta=112.197(4)^{\circ}, \gamma=$ 97.717(4) $)^{\circ}, \mathrm{V}=830.4(2) \AA^{3}, \mathrm{Z}=2, \mathrm{~T}=173(2) \mathrm{K}, 11653$ reflections collected, 4054 unique reflections $\left(\mathrm{R}_{\text {int }}=0.0366\right), \mathrm{R} 1=0.0276, \mathrm{wR} 2=0.0679[\mathrm{I}>2 \sigma(\mathrm{I})], \mathrm{R} 1=0.0320, \mathrm{wR} 2=0.0702$ (all data), residual electron density $=2.108 \mathrm{e} \AA^{-3}$.

\subsection{Biological material and methods}

\subsubsection{In vitro antimalarial activities}

The in vitro antimalarial activities of the 25 synthesized compounds were tested comparatively to their ligands in order to determine the influence of the different structure modulations on the biological activities. Both chloroquine-resistant P. falciparum strains FcM29-Cameroon and FcB1-Colombia, were cultured continuously according to the modified Trager and Jensen's method. ${ }^{21}$ The antimalarial activity was evaluated by the radioactive micromethod described by Desjardins et al. ${ }^{22}$ with modifications as reported. ${ }^{23}$

Drug testing was performed from 2 to 5 times in triplicate in 96-well culture plates on D-sorbitol synchronized cultures. Compounds were dissolved in dimethylsulfoxide (DMSO) (stock solution: $10 \mathrm{mg} / \mathrm{mL}$ ) and further diluted in culture medium so that the final DMSO concentration never exceeded $2 \%$. For each assay, it was verified that the $2 \%$ concentration of 
DMSO did not affect parasite growth. Parasite growth was estimated by $\left[{ }^{3} \mathrm{H}\right]$ hypoxanthine incorporation (Perkin Elmer, France).

The control parasite culture (culture medium with or without $2 \%$ DMSO) was referred to as $100 \%$ growth. The $\mathrm{IC}_{50}$ values were determined graphically by plotting the log of the drug concentration versus the percentage inhibition of parasite growth. Results are summarized in Table 1.

\subsubsection{Cytotoxicity assays}

Evaluation of the cytotoxicity of selected compounds was performed on Vero cell lines (Monkey epithelial cell line, Sigma-Aldrich) or on McF7 cell line with the same dilution protocol used for antiplasmodial assays. Cell lines were distributed in 96-well plates in $100 \mu \mathrm{L}$ MEM medium with $10 \%$ foetal calf serum at $37{ }^{\circ} \mathrm{C}$ under a humidified atmosphere $\left(5 \% \mathrm{CO}_{2}\right)$. After $24 \mathrm{~h}$-culture, the cells were supplemented with $100 \mu \mathrm{L}$ of the compounds dilutions and $\left[{ }^{3} \mathrm{H}\right]$ hypoxanthine was also added for $48 \mathrm{~h}$ more. Cell growth was estimated by $\left[{ }^{3} \mathrm{H}\right]$ hypoxanthine incorporation read by $\beta$ counter (1450-Microbeta Trilux, Wallac-Perkin Elmer) as reported for antiplasmodial assays. ${ }^{24}$ Selectivity index was then calculated by the Cytotoxicity/Activity ratio.

\section{Acknowledgements}

This work was supported by the Centre National de la Recherche Scientifique (CNRS). APR obtained a PhD grant from DIKTI - Indonesia.

\section{References and notes}

1. WHO, World Health Organization. World Malaria Report 2015. 2015. 280 p.

2. Alessio, E., Bioinorg Med Chem. Germany 2011; Vol. 10.

3. Salas, P. F.; Herrmann, C.; Orvig, C. Chem. Rev. 2013, 113, 3450. 
4. (a) Navarro, M.; Castro, W.; Martínez, A.; Sánchez-Delgado, R. J. Inorg. Biochem. 2011, 105, 276; (b) Martinez, A.; Rajapakse, C. S. K.; Jalloh, D.; Dautriche, C.; SanchezDelgado, R. A. J. Biol. Inorg. Chem. 2009, 14, 863; (c) Navarro, M.; Vasquez, F.; Sanchez-Delgado, R. A.; Perez, H.; Sinou, V.; Schrevel, J. J. Med. Chem. 2004, 47, 5204; (d) Sánchez-Delgado, R.; Navarro, M.; Pérez, H. J Chem Med 1997, 40, 1937; (e) Sanchez-Delgado, R. A.; Navarro, M.; Perez, H.; Urbina, J. A. J. Med. Chem. 1996, 39, 1095.

5. (a) Biot, C.; Glorian, G.; Maciejewski, L. A.; Brocard, J. S.; Domarle, O.; Blampain, G.; Millet, P.; Georges, A. J.; Abessolo, H.; Dive, D.; Lebibi, J. J. Med. Chem. 1997, 40, 3715; (b) Chavain, N.; Vezin, H.; Dive, D.; Touati, N.; Paul, J. F.; Buisine, E.; Biot, C. Mol. Pharm. 2008, 5, 710; (c) Biot, C.; Nosten, F.; Fraisse, L.; Ter-Minassian, D.; Khalife, J.; Dive, D. Parasite 2011, 18, 207; (d) Biot, C.; Pradines, B.; Dive, D., Drug Discovery in Infectious Diseases. 2011; (e) Dubar, F.; Bohic, S.; Slomianny, C.; Morin, J. C.; Thomas, P.; Kalamou, H.; Guerardel, Y.; Cloetens, P.; Khalife, J.; Biot, C., Chem Comm 2012, 48, 910; (f) ClinicalTrials.gov, http://clinicaltrials.gov/ct2/show/NCT00988507 https://clinicaltrials.gov/ct2/show/NCT02497612

6. Chavain, N.; Davioud-Charvet, E.; Trivelli, X.; Mbeki, L.; Rottmann, M.; Brun, R.; Biot, C., Bioorg. Med. Chem. 2009, 17, 8048.

7. (a) Teyssot, M. L.; Jarrousse, A. S.; Manin, M.; Chevry, A.; Roche, S.; Norre, F.; Beaudoin, C.; Morel, L.; Boyer, D.; Mahiou, R.; Gautier, A. Dalton Trans. 2009, 6894; (b) Hindi, K. M.; Panzner, M. J.; Tessier, C. A.; Cannon, C. L.; Youngs, W. J. Chem. Rev. 2009, 109, 3859; (c) John, A.; Ghosh, P. Dalton Trans. 2010, 39, 7183; (d) Mercs, L.; Albrecht, M. Chem. Soc. Rev. 2010, 39, 1903; (e) Gasser, G.; Ott, I.; Metzler-Nolte, N., J. Med. Chem. 2011, 54, 3; (f) Gautier, A.; Cisnetti, F. Metallomics 2012, 4, 23; (g) Patra, M.; Gasser, G.; Metzler-Nolte, N. Dalton Trans. 2012, 41, 6350; (h) Liu, W. K.; Gust, R. Chem. Soc. Rev. 2013, 42, 755; (i) Oehninger, L.; Rubbiani, R.; Ott, I. Dalton Trans. 2013, 42, 3269; (j) Bertrand, B.; Casini, A. Dalton Trans. 2014, 43, 4209; (k) Tacke, M. J. Organomet. Chem. 2015, 782, 17.

8. (a) Boselli, L.; Ader, I.; Carraz, M.; Hemmert, C.; Cuvillier, O.; Gornitzka, H. Eur. J. Med. Chem. 2014, 85, 87; (b) Boselli, L.; Carraz, M.; Mazeres, S.; Paloque, L.; Gonzalez, G.; Benoit-Vical, F.; Valentin, A.; Hemmert, C.; Gornitzka, H. Organometallics 2015, 34, 1046; (c) Hemmert, C.; Fabie, A.; Fabre, A.; Benoit-Vical, F.; Gornitzka, H. Eur. J. 
Med. Chem. 2013, 60, 64; (d) Paloque, L.; Hemmert, C.; Valentin, A.; Gornitzka, H. Eur. J. Med. Chem. 2015, 94, 22.

9. Lin, J. C. Y.; Huang, R. T. W.; Lee, C. S.; Bhattacharyya, A.; Hwang, W. S.; Lin, I. J. B. Chem. Rev. 2009, 109, 3561.

10. Wein, S.; Maynadier, M.; Bordat, Y.; Perez, J.; Maheshwari, S.; Bette-Bobillo, P.; Tran Van Ba, C.; Penarete-Vargas, D.; Fraisse, L.; Cerdan, R.; Vial, H. Br. J. Pharmacol. 2012, $166,2263$.

11. Kuhn, Y.; Rohrbach, P.; Lanzer, M. Cell Microbiol 2007, 9, 1004.

12. Glisic, B. D.; Djuran, M. I. Dalton Trans. 2014, 43, 5950.

13. Micale, N.; Cinellu, M. A.; Maiore, L.; Sannella, A. R.; Severini, C.; Schirmeister, T.; Gabbiani, C.; Messori, L. J. Inorg. Biochem. 2011, 105, 1576.

14. (a) Khanye, S. D.; Wan, B.; Franzblau, S. G.; Gut, J.; Rosenthal, P. J.; Smith, G. S.; Chibale, K. J Org Chem 2011, 696, 3392; (b) Khanye, S. D.; Smith, G. S.; Lategan, C.; Smith, P. J.; Gut, J.; Rosenthal, P. J.; Chibale, K. J. Inorg. Biochem. 2010, 104, 1079.

15. Schuh, E.; Valiahdi, S. M.; Jakupec, M. A.; Keppler, B. K.; Chiba, P.; Mohr, F. Dalton Trans. 2009, 10841.

16. Molter, A.; Rust, J.; Lehmann, C. W.; Deepa, G.; Chiba, P.; Mohr, F. Dalton Trans. 2011, 40,9810 .

17. Lambros, C.; Childs, G. E.; Notsch, J. D.; Scovill, J. P.; Klayman, D. L.; Davidson, D. E. Antimicrob. Agents Chemother. 1982, 22, 981.

18. Coetzee, J.; Cronje, S.; Dobrzanska, L.; Raubenheimer, H. G.; Joone, G.; Nell, M. J.; Hoppe, H. C. Dalton Trans. 2011, 40, 1471.

19. Sheldrick, G. M. Acta Cryst. 1990, A46, 467.

20. Sheldrick, G. M. Acta Cryst. 2008, A64, 112.

21. Benoit-Vical, F.; Robert, A.; Meunier, B. Antimicrob. Agents Chemother. 2000, 44, 2836.

22. Desjardins, R. E.; Canfield, C. J.; Haynes, J. D.; Chulay, J. D. Antimicrob. Agents Chemother. 1979, 16, 710.

23. Benoit-Vical, F.; Lelievre, J.; Berry, A.; Deymier, C.; Dechy-Cabaret, O.; Cazelles, J.; Loup, C.; Robert, A.; Magnaval, J. F.; Meunier, B. Antimicrob. Agents Chemother. 2007, $51,1463$.

24. Benoit-Vical, F.; Soh, P. N.; Salery, M.; Harguem, L.; Poupat, C.; Nongonierma, R., J. Ethnopharmacol. 2008, 116, 43. 
Graphical abstract

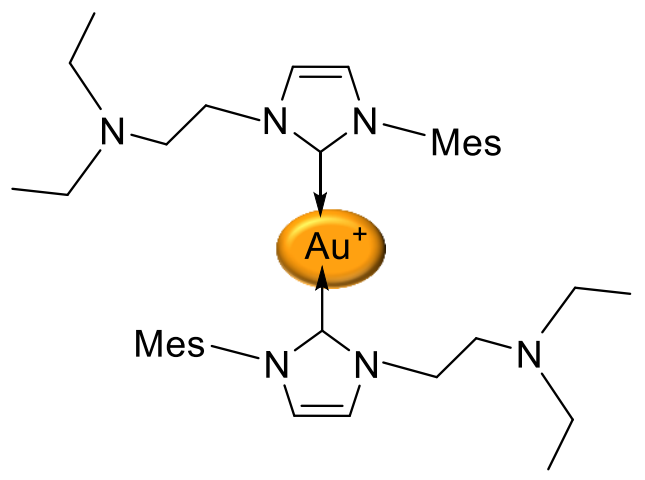

Plasmodium

falciparum

$\mathrm{IC}_{50}=210 \mathrm{nM}$ 